\title{
SANCTION MECHANISM OF THE REGISTER OF PUBLIC SECTOR PARTNERS IN CONTEXT OF PUBLIC PROCUREMENT ${ }^{1}$
}

\author{
Zuzana Kršjaková \\ Office for Public Procurement, Slovak Republic
}

KRŠJAKOVÁ, Z. Sanction Mechanism of the Register of Public Sector Partners in Context of Public Procurement. Bratislava Law Review, Vol. 3, No. 2 (2019), pp. 18 - 33. ISSN 2585-7088, eISSN: 2644-6359

\begin{abstract}
This paper is dedicated to the comprehensive regulation of obligations related to the registration in the Register of Public Sector Partners which can be identified in a variety of legal provisions. The paper deals with all sanctions related to meeting these obligations. The introduction defines what the Register of Public Sector Partners is and with what purpose it has been established. Afterwards, the paper focuses on the identification of individual regulations which include the obligations related to the Register of Public Sector Partners, as well as the individual sanctions for not meeting them. The last part of the paper shifts attention to the private law aspects of violations of obligations related to the Register of Public Sector Partners.
\end{abstract}

Key words: Register of Public Sector Partners, public procurement, violation of obligation, sanction, contract withdrawal, offense, Public Procurement, Slovak law

\section{INTRODUCTION}

The Register of Public Sector Partners is a register in which registration is a pre-requisition for business opportunities in the so-called public sector, i.e. with the state, legal persons established by the state, municipalities, higher territorial units, and so on. The aim of the Register of Public Sector Partners, also called the anti-box register, is to prevent companies with unclear ownership structure or even unclear property background from forming business relationships with the public sector. The Register of Public Sector Partners is a successor of the End Benefit User Register. The administration and carrying out of individual entries into the End Benefit User Register was in the competence of the Office for Public Procurement.

The scope of competences of the Office for Public Procurement in the End Benefit User Register followed from the very goal of this register, i.e. to identify the persons making business with the state, resp. forming contractual relationships with the state. The aim of the new legislation is, in particular, to publish correct and complete data on end users of benefits of the registered entities.

Besides the new obligations, the Register of Public Sector Partners has also introduced the noncompliance sanctions for violating these obligations as well. These are regulated at several levels. This article aims to discuss individual sanctions connected to a violation of obligations following from registration into the Register of Public Sector Partners, as well as other options within the

1 This article was supported by grant APVV-17-0641: „Zefektívnenie právnej úpravy verejného obstarávania a jej aplikácie v kontexte práva Európskej únie." 
contractual relationships themselves which are established between the "public sector partners" and the state.

\section{REGISTER OF PUBLIC SECTOR PARTNERS AND INDIVIDUAL SANCTIONS}

The Register of Public Sector Partners was introduced into the Slovak legislation with Act No. 315/2016 Coll. of Laws on Register of Public Sector Partners (hereinafter referred to as "Register of Public Sector Partners Act"). As already mentioned in the introduction, the Register of Public Sector Partners is a successor of the End Benefit User Register which was administrated by the Office for Public Procurement and by which the obligation to register followed from the Act on Public Procurement. The Register of Public Sector Partners should cover a more complex area of legal relationships compared to the End Benefit User Register.

The End Benefit User Register was dealt with contractual relationships concluded pursuant to Act No. 343/2015 Coll. of Laws on public procurement (hereinafter referred to as "Public Procurement Act") and thus dealt with contractual relationships which resulted from public procurement. The Register of Public Sector Partners deals with a wider scope of social relations, not only those related to Public Procurement Act.

Regardless of this, however, the aim of both registers was the identification of the end user of benefits in a concrete legal person. At the same time, there is a difference in the definition of the end user benefits, as well as how to identify the end user of benefits. The Register of Public Sector Partners uses for the purpose of identification Act No. 297/2008 Coll. of Laws on protection from legalisation of income from criminal activities and on protection from financing of terrorism. This Act includes wide identification criteria for identification of the end user of benefits. In short, pursuant to this Act, the end user of benefits is each natural person which actually manages or controls a legal person, a natural person - an entrepreneur or association of property, and each natural person to benefit of whom these entities carry out their activities or business. ${ }^{2}$

In accordance with this, the aim of the Register of Public Sector Partners is to identify the end users of benefits and to publicize them in a wider measure of legal relationships into which enters the state and its individual entities. From the comparison between the Register of Public Sector Partners and the End Benefit User Register follows that to register in the Register of Public Sector Partners are obliged not only the economic operators concluding a contract as the result of public procurement, but also other entities which receive funds from the state, the European Union, as well as from other legal persons established by law, from public enterprises, from public healthcare insurance, eventually from state aid, entities which receive certain licences or have financial claims to the public sector.

To register in the Register of Public Sector Partners are obliged natural or legal persons which might be, pursuant to Register of Public Sector Partners Act, divided into 6 groups. The Register of Public Sector Partners Act includes a broad definition who is considered a public sector partner, as well as negative definition who is not a public sector. To simplify this, the individual entities are ordered into the below listed groups.

2 https://www.slov-lex.sk/pravne-predpisy/SK/ZZ/2008/297/\# 


\subsection{Public Sector Partners and Responsibility Relationships which Might Arise in Connection with Registration}

The first group, which pursuant to the Public Sector Partners Act can be identified as public sector partners, are recipients of public funds if the value of the one-time received fulfilment exceeds the amount of $€ 100,000$ or the value of a repeatedly received fulfilment cumulatively exceeds the amount of $€ 250,000$.

This includes, in particular, legal persons, entrepreneurs participating in public tenders, whether in position of a contractor or sub-contractor, as well recipients of various kinds of subsidies and contributions (e.g. from state funds, budgets of municipalities, regions, public organisations or European Structural Funds). The significant sign for assessment whether an individual entity is a public sector partner in this group of entities is the fact that it entered or should enter into a contractual relationship in which it would receive one-time or repeated financial fulfilment of defined value.

The second groups are the recipients of non-financial fulfilment (property or rights) which value exceeds the amount of $€ 100.000$. This group can include recipients of property or rights for property owned by the state, public institution, municipality, higher territorial unit, legal person established by law, or public company.

The third group of public sector partners consist of healthcare providers which have concluded a contract with health insurance companies on provision of healthcare. On the basis of this contract these public sector partners will be provided with one-time financial fulfilment exceeding the amount of $€ 100,000$ or repeated financial fulfilment which value cumulatively exceeds the amount of $€ 250,000$. The contract for provision of healthcare is concluded between health insurance companies and various healthcare providers, both state as well as private healthcare providers. Pursuant to Public Sector Partner Act, as public sector partners which are obliged to register in the Register of Public Sector Partners are considered private providers whose performance is reimbursed by a health insurance company. This applies only in the case if they reach the financial limits mentioned above, however.

As the fourth group of public sector partners we identify the persons which are obliged to register in the register established by the Health Insurance Companies Act regardless of the fact whether they do business or otherwise cooperate with the public sector, as well as regardless of the value of financial or non-financial fulfilment.

A specific group of public sector partners are the sub-contractors (and their representatives) of the public sector partners identified in the previous groups if they are provided with one-time financial fulfilment exceeding the amount of $€ 100.000$ or repeatedly received fulfilment which value cumulatively exceeds the amount of $€ 250.000$, as well as the sub-contractors which directly or indirectly deliver goods and services to persons within the groups from 1 to 4 , or which receive property or rights from these persons in the above listed values.

The last group are persons which have financial claims to the state, state fund, public institution, municipality, higher territorial unit, or legal person established by law with the exception of a chamber established by law one-time in the value over $€ 100,000$ or repeatedly cumulatively in the value over $€ 250,000$.

Outside of the above mentioned persons, the Register of Public Sector Partners includes automatically registered entities which had been previously registered in the End Benefit User Register. 
If a legal or natural person concludes that they are a public sector partner, they are obliged to register in the Register of Public Sector Partners. The registration in the Register of Public Sector Partners is carried out by the so called authorized entities. The public sector partner itself cannot issue a registration proposal and such registration proposal ought to be denied by the registration body. If the entity meets the criteria and thus is obliged to register in the Register of Public Sector Partners, it has to task an authorized entity to do so. Pursuant to law, as an authorized entity is only understood a lawyer, notary, bank, auditor or tax consultant with residence or base of entrepreneurship in the territory of the Slovak Republic and, at the same time, a foreign entity authorized to carry out in the territory of the Slovak Republic the same activity as an authorized entity pursuant to the previous sentence, under the condition that it has its business or organisational unit situated in the territory of the Slovak Republic. ${ }^{3}$ This entity becomes an authorized entity on the basis of a concluded contract with a public sector partner. Afterwards, the authorized entity carries out the registration the public sector partner. Within this act, it is identified who is the end user of benefits of the partner. The identification of the end user of entrepreneurship benefits is the point of the Public Sector Partners Registration.

The provisions on the Public Sector Partners are provisions of public law and mandatory. They present a significant impact on contractual relationships between business partners if one of them is the state, resp. an entity established by the state. Of course, the Register of Public Sector Partners aims to meet important goals. Its existence is justified, however, it is not usual for the state to be forced to take such significant steps in order to provide transparent usage of public funds. This intervention into contractual relationship and limitation of economic operators itself is, however, justified by the interest of the state to identify the persons with which the state enters into contractual relationships and which receive public funds. Another significant reason is the interest to establish conditions for public control. However, the expert public holds a variety of views on the Register of Public Sector Partners.

The Register of Public Sector Partners is administrated by the District Court in Žilina which carries out the registration entries, amendments, erasures, as well as conducts infringement proceedings by a violation of obligations pursuant to Register of Public Sector Partners Act.

Pursuant to the information mentioned above, by the act of registration in the Register of Public Sector Partners arise obligations on the side of the public sector partner, as well as on the side of the authorized entity. In addition to these two groups of entities, which may constitute a basic prerequisite for non-compliance, there is another group of entities that enter into contractual relationships with public sector partners that are not complying with their obligations under the Register of Public Sector Partners Act. In accordance with this, the sanction mechanisms for the cases of non-compliance with the obligation introduced by Public Sector Partners Registry Act for the public sector partners and for the authorized entities are introduced directly by Public Sector Partners Registry Act.

In addition to the sanction mechanism in the Register of Public Sector Partners Act, separate obligation along its penalisation is regulated by Public Procurement Act. Obligations in the sector of Register of Public Sector Partners regulated in Public Procurement Act are imposed for contracting authorities and contracting entities and, at the same time, sanctions are imposed on contracting authorities and contracting entities as well.

3 https://www.justice.gov.sk/Stranky/Registre/Dalsie-uzitocne-zoznamy-a-registre/RPVS/FAQ.aspx 
The last group for which a sanction mechanism has been introduced to ensure compliance is the statutory bodies of the public sector partners. The sanction for a violation of their obligation is defined in Act No. 372/1990 Coll. of Laws on offenses (hereinafter referred to as "Offense Act").

\subsection{Sanctions and Responsibility pursuant to Register of Public Sector Partners Act}

The authorized entities are by registering the public sectors partner in the Register of Public Sector Partners obliged to act with professional care. Register of Public Sector Partners Act defines precisely the situations when they cannot carry out duties of the authorized entity. The authorized entity cannot carry out their duties if they are in the very same case the public sector partner or end user of benefits of the public sector partner for whom they should carry out duties of the authorized entity, the end user of benefits of the public sector partner and the authorized entity are the same natural person, or if they share any relationship with the public sector partner or if they are a member of their bodies which might call into question their impartiality, in particular, if they are connected with the public sector partner on the personal or property level.

According to this, the authorized entity is obliged to carry out their activities independently and impartially. They should not, while carrying out other activities, get into conflict of interests with the activities of the authorized entity for specific public sector partners or other specific end users of benefits.

The registrant - the court - can on the basis of its own initiative or a proposal from other entities verify whether the data on the end user of benefits saved in the Register of Public Sector Partners are true and complete. If the public sector partner cannot reliably demonstrate that the data on the end user of benefits in the register are true and complete, the registrant makes a decision on the erasure of the public sector partner from the register. This does not apply if, given the manner in which the obligation is violated, its consequences, the circumstances in which the obligation was breached and the degree of fault, the gravity of the infringement is negligible.

After the erasure decision has become final because the data on the end user of benefits were not entered in the register, resp. if they are not true and complete, the court will remove the public sector partner from the register and initiate a fine procedure. No legal remedies shall be admissible against the court's decision on erasure.

The sanctions imposed pursuant to Register of Public Sector Partners Act can be imposed on the authorized entities, public sector partners, end users of benefits, and statutory bodies of the public sector partner. Register of Public Sector Partners Act enables to impose two different types of sanctions for other administrative offences. These are financial fines and erasure from the Register of Public Sector Partners.

The first other administrative offense in the sector of the Register of Public Sector Partners is the inclusion of false or incomplete data on the end user of benefits or public officials in the application for registration, which can be sanctioned for both the public sector partner and its statutory body. The public sector partner shall be fined for misrepresentation or incomplete data in the amount of atypical amount of economic benefit received by the public sector partner and, if this cannot be ascertained, between $€ 10,000$ and $€ 1,000,000$.

Outside of this, for this offense is also sanctioned the statutory body, resp. the person who is the statutory body or which is collectively a member of the statutory body in the time of a violation of the above mentioned obligation with a fine between $€ 10,000$ and $€ 100,000$. The fine imposed on 
the statutory body is also guaranteed by the authorized entity which was registered as the authorized entity in the time of a violation of the obligation. The difference compared to the fine imposed on the public sector partner or the statutory body by this offense is that the authorized entity is not obliged to pay the fine for which they guarantee if it is demonstrated that the authorized entity acted with professional care.

The same fines shall also be imposed by the court if the obligation to submit a proposal to amend the registered data related to the end user of benefits within the set time limit is not met, as well as if the ban to carry out the activities of the authorized entity is violated. In addition to these two offenses, the court also shall erase the public sector partner from the Register of Public Sector Partners if the fine was legally imposed but not paid within the set time limit.

Another sanction for public sector partners if the registrant carries out the erasure of a public sector partner due to the above mentioned reasons is that the public sector partner cannot be registered in the Public Sector Partner Registry again 2 years since the erasure. Outside of the register entry ban, resp.

Another sanction for the public sector partner in case of the registrant erases the public sector partner due to the above mentioned reasons is that the public sector partner cannot be registered again two years since their erasure. In addition to registration ban, the decision on erasure, respectively on erasure of the public sector partner from the Register of Public Sector Partners due to a violation of obligations, is at the same time the decision on exclusion pursuant to paragraph 13a of Act No. 513/1991 Coll. of Commercial Code (hereinafter referred to as "Commercial Code"). As the excluded entity is understood the statutory body or the members of the statutory body of a legal person registered in the Commerce Register who is a public sector partner and who has been erased from the Register as described above. The decision on exclusion means that these entities cannot, in any commercial company or cooperative, carry out the function of a statutory organ member or a supervision body member within three years since the day this decision has come into force.

As already stated, in addition to sanctioning the public sector partner and the statutory body the court also imposed a fine to the end user of benefits if they do not meet their obligations imposed by the law. A fine up to $€ 10,000$ is imposed on the end user of benefits if they, within 15 days since they learned that they have become the end user of benefits of the public sector partner, do not inform the public sector partner that as the registered authorized entity they have become their end user of benefits.

As the last entity which can violate the obligations arising from Public Sector Partner Act is the authorized entity. The authorized entity will be fined by court the amount ranging from $€ 10,000$ up to $€ 100,000$ if the authorized entity violates the ban mentioned above, i.e. if they carry out duties of the authorized entity if they are, in the very same case, the public sector partner or the end user of benefits of public sector partner for whom they should carry out the obligations of the authorized entity, if the end user of benefits of a public sector partner and the authorized entity are the same natural person, or if they have any relationship with the public sector partner or if they are a member of their bodies which might call into question their impartiality, in particular, if they are connected with the public sector partner on the personal or property level.

The authorized entity, at the same time, as the only obliged entity provides with possibility of legal remedy, but only in the case of a decision on a fine imposed on the statutory body for paying which the authorized entity guarantees. Outside of the case of optional legal remedy application, 
in other cases of imposing of fines Register of Public Sector Partners Act does not allow any other legal remedies.

In addition to not being able to use legal remedies, another specific item by imposition of fines pursuant to Register of Public Sector Partners Act is the amount of the imposed fine on the public sector partner. Register of Public Sector Partners Act introduces a sanction, a fine in the amount of economic benefit the public sector partner has achieved.

In this case the primary goal of the sanction imposed on the public sector partner pursuant to paragraph 13 Section 1 (a) is to take away economic benefit the public sector partner gained in case of a violation of their obligations pursuant to Register of Public Sector Partners Act. Under the term "economic benefit" is to be understood any financial income or financially quantified increase of property or its value following form a contract or an agreement which does not correspond with direct, demonstrable and valid costs of the public sector partner used for fulfilling the contract or the agreement (authorized costs). The method for economic benefit calculation depends on the contract subject. One method presents the difference between the price the public sector entity paid to the public sector partner for delivery of goods or services and the funds the public sector partner used to procure, resp. produce/provide the goods or services which are the contract subject and have been delivered. Therefore, it analogically follows that if the public sector partner has obtained property, rights to property or property rights, economic benefit presents the difference between the funds used for these rights and the market value the public sector partner has obtained. The aim of the lawmaker is to take away from the sanctioned public sector partner any profit from this transaction. For this purpose, it is necessary to carefully review the legitimacy of used costs of the obliged entity. A fine starting from $€ 10,000$ up to $€ 1,000,000$ is only imposed if economic value is not possible to evaluate. By imposing the fine the court takes into consideration the nature, severity, method, and consequences of a violation of obligation.

\section{$3 \quad$ SANCTIONS PURSUANT TO OTHER LEGAL PROVISIONS}

As already follows from Register of Public Sector Partners Act mentioned above, there are other legal provisions dealing with other groups of responsibility relationships, particularly on the part of the state. These are the Public Procurement Act, as well as Offense Act. The responsibility due to Act 300/2005 Coll. of Laws on Criminal Code (hereinafter referred to as "Criminal Code").

The general obligation of each entity is to obey the law. A violation of law obligations is bound to a variety of responsibilities. If the unlawful conduct fulfils the constituent elements of the public-law offense, the public authorities incur criminal or administrative liability. ${ }^{4}$

\subsection{Public Procurement Act}

Prior to Register of Public Sector Partners Act, Public Procurement Act involved complex legislation related to definition of end user of benefits in by successful candidates in public procurement. The aim of this original legislation was to uncover the property structure of the successful candidate. ${ }^{5}$

\footnotetext{
MACHAJOVÁ, J. General Administrative Law. Žilina: EUROKÓDEX, s. r. o., 2014, p. 249.

GRIGA, M., TKÁČ, J. Public Procurement Law. Commentary. Bratislava. Wolters Kluver, s. r. o. 2016 , p. 64
} 
Public Procurement Act deals with obligations of contracting authority - the Slovak Republic represented by its bodies, municipalities, higher territorial units, legal persons established for a specific reason of meeting needs of common interest, all of which do not have industrial or commercial nature, and they are, either entirely or for the most part, funded by the contracting authority, is controlled by the contracting authority or the contracting authority appoints or elects more than a half of the managing body members or control body, an association of legal persons which members are exclusively contracting authorities. Furthermore, the obligations pursuant to Public Procurement Act in the section of the Register of Public Sector Partners are also applied on a contracting entity as well. A contracting entity is a legal person on which the contracting entity has direct or indirect controlling influence on the basis of property right, financial share or rules through which there is managed or carried out at least one of the activities defined by Public Procurement Act such as activities in power engineering, gas industry, thermal energy, water industry, logistics, post services, i.e. natural state monopolies. At the same time, this can be a legal person who carries out these activities on the basis of specific and exclusive rights. As controlling influence is understood that the contracting authority owns directly or indirectly majority of the shares or a majority holding, controls a majority share in voting rights or appoints more than a half of the managing body members or another executive body or control body. ${ }^{6}$

Considering the new Register of Public Sector Partners came into force, as well the differentiation of social relations which are mandatory to be reported and which reveal the end users of benefits, Public Procurement Act only includes the obligation defined in paragraph 11, as well as the non-compliance sanction. Public Procurement Act and the introduced obligation follow the interest to reveal end users of benefits on the part of the state. The contracting authorities and contracting entities, i.e. a huge group of state entities which enters into contractual relationships with the public sector partners cannot conclude a contract, concession contract or framework contract pursuant to Public Procurement Act with an entity which is obliged to be registered in the Register of Public Sector Partners and is, in fact, not. For completeness it is necessary to note that the contract conclusion ban is not related to a framework agreement which is concluded with contracting authorities or contracting entities by two or more candidates who are natural persons and which deals with provision of services.

The practical aspect of this ban is the mandatory control carried out by the contracting authority and contracting entity, so that they verify before the contract conclusion whether their contractual partner along all their sub-contractors are registered in the Register of Public Sector Partners if this obligation pursuant to Register of Public Sector Partners Act applies to them.

By violating this obligation on the part of the contracting authority or contracting entity the Office for Public Procurement imposes on the contracting authority or contracting entity a fine in the amount of $5 \%$ of the contract price of contract which has been concluded in a violation with the ban. Public Procurement Act is in the section of administrative punishment framed on the principle of objective liability which is based on the fact that by meeting the merits of administrative offense the managing body does not review the subjective part of law violation, intention or negligence, but only the conflict between the legal status and the actual one. Next, it is important to stress that this sanction has not been introduced as an option. It is a sanction the Office for Public Procurement shall impose regardless of the severity of taken actions, amount of negotiated price, length of a violation of obligation on the part of the contracting authority or contracting entity.

6 https://www.slov-lex.sk/pravne-predpisy/SK/ZZ/2015/343/20160418.html 
In this case, the sanction is determined by exact rate and does not allow for considerations where would it be possible to take into account the kind of a law violation of contract conclusion, as well as the impact on the protected law interest - the state interest to uncover and identify the end users of benefits and funds provided from the state budget. The sanction, in some cases, can appear to be as inappropriately strict, however, the end decision is possible after exhaustion of legal remedies to review by the court which has the option to change the type or value of the sanction, even if the public administration body has not stepped out of the legal framework of the consideration, should this sanction not be appropriate to the nature of the act or if it would liquidate the applicant, or to refrain from imposing a sanction if the purpose of the administrative punishment can also be achieved by the actual hearing of the case.

Administrative punishment is one form of deducing administrative liability. The managing body by administrative punishment also has other power resources which are, by law, to be used to enforce meeting law liabilities by the obliged entity, renew the original state, prevent a further law violation in public administration etc. ${ }^{7}$ If the contractual relationship concluded despite the contract conclusion ban has been concluded, the concession contract or framework agreement with the entity which (or whose sub-contractors) is not registered in the Register of Public Sector Partners despite this obligation the Office for Public Procurement has active legitimacy to submit a proposal to nullify this contract. The proposal is to be submitted within one year since contract conclusion.

\subsection{Offense Act and Other Legislation}

Public Procurement Act pursues the obligation of the public sector to also meet the obligations of public sector partners in relation to the Register of Public Sector Partners. Public Procurement Act establishes obligations directly for legal persons, contracting authorities and contracting entities, while the lawmaker also imposed obligations to the statutory body of the contracting authorities and contracting entities and pursues their fulfilment through the option to impose sanctions.

Offense Act has introduced a new type of offenses - offense by registration of the public sector partners. This offense has only been committed by an entity which has concluded a contract with the public sector partner if the public sector partner was not, on the day of contract conclusion, registered in the Register of Public Sector Partners. ${ }^{8}$

Offenses are the most often occurring and, in theory, most detailed type of administrative delicts. An offense is characterized as one of the kinds of administrative delicts by natural persons and offense proceeding is a proceeding dealing only with this kind of administrative delicts. The law defines an offense as a guilty act which violates or endangers the public interest and is explicitly labelled in Offense Act or in another law if it is not another administrative delict or criminal act. ${ }^{9}$

The legal consequence of committing an offense is, in this case, the sanction in the form of a fine. Offense Act pursues in this particular instance adherence to the obligation on the part of a natural person, statutory body which directly concludes a contract with the public sector partner. The sanction for a violation of obligation is the option to impose a fine starting at $€ 1,000$ up to $€ 100,000$. The essence of the sanction is the cost that arises to the offender, eventually their moral condemnation

MACHAJOVÁ, J. General Administrative Law. Žilin a: EUROKÓDEX, s. r. o., 2014, p. 251.

https://www.slov-lex.sk/pravne-predpisy/SK/ZZ/1990/372/

ŠEVČÍK, M. Administrative Procedural Law. Bratislava : EURONION, spol. s r. o. 2007, p. 12. 
as well. Often, it interferes with their constitutional rights. It is, however, intended to be educational and deter the offender from committing illegal acts. The sanction is not an obligatory legal consequence of an offense. It is possible to refrain from imposing a sanction if hearing on the offense is deemed as sufficient to correct the offender. Refrain from imposing the sanction for an offense assumes that the administrative body makes a decision on whether the offender is guilty or not. The law pre-condition, therefore, in this case is not that the offense presents less severe harm on the society, state of sanity, demonstrated regret etc. The managing body is obliged to review whether the hearing on the offense on its own is sufficient to correct the offender. ${ }^{10}$

The introduction of liability and sanctions on the part of a natural person who by contract conclusion acts directly with the public sector partner which violated the obligations can be considered as a comprehensive regulation of relations in the sector of the public sector register and achieving its purpose.

The complexity of the regulation can be also noted by the introduction of new obligations in other legal provisions, such as in case of Act No. 92/1991 Coll. of Laws on Conditions for Transfer of State Property where the condition for obtaining privatized property is registering in the Register of Public Sector Partners, or in case of Act No. 138/1991 Coll. on Municipality Property the condition for registering in the Public Sector Partners Registry if by obtaining the municipality property are met the conditions. Further example is Act No. 278/1993 Coll. of Laws on State Property Management where the condition for obtaining state property which is registering in the Register of Public Sector Partners. The conditions for registering in the Register of Public Sector Partners are also present in Act No. 446/2001 Coll. of Laws on Higher Territorial Units Property, Act No. 527/2002 Coll. of Laws on Voluntary Auctions, Act No. 176/2004 Coll. of Laws on Public Institutions Property Management, Act No. 523/2004 on Budget Rules for Public Administration, Act No. 581/2004 Coll. of Laws on Health Insurance Companies, Act No. 561/2007 Coll. of Laws on Investment Aid, Act No. 292/2014 Coll. of Laws on Contributions Provided by the European Structural and Investment Funds.

All of the above mentioned legal provisions include the obligation to register in the Register of Public Sector Partners pursuant to Register of Public Sector Partners Act. Although these legal provisions do not include the sanction itself, for this purpose it is necessary to use sanction mechanisms on the level of other provisions. However, if legal acts are carried out in contradiction with these legal provisions, it is justified to deal with possible validity of performed legal acts.

Pursuant to the provision of paragraph 39 of Act No. 40/1964 Coll. of Civil Code (hereinafter referred to as "Civil Code") as invalid counts only such a legal act which nature or purpose contradicts the law or evades it or violates good morals. In the mentioned case it would absolutely mean that the legal act were invalid.

\subsection{Liability pursuant to Criminal Code}

The above mentioned legal provisions deal with administrative liability for a violation of obligations related to registration of the public sector partners in the Register of Public Sector Partners. In addition to administrative liability is also not excluded the possibility that a violation of obligations in the sector of the public sector partners will also establish criminal obligation and that by violating one of the obligations one of the crimes regulated by Criminal Code will be committed. First of all, it is necessary to note that Register of Public Sector Partners Act has introduced a new condition

10 MACHAJOVÁ, J. General Administrative Law. Žilina : EUROKÓDEX, s. r. o., 2014, p. 269. 
for access to public funds. This is condition is registration in the Register of Public Sector Partners. It is without a doubt that only this registration is considered as the complete and true registration in the Register. A violation of this obligation can lead not only to administrative punishment, but also to criminal punishment as well. Into consideration also comes, in particular, the crime of fraud pursuant to paragraph 221 of Criminal Code, crime of subsidy fraud pursuant to paragraph 225 of Criminal Code, and crime of distortion of economic and commercial data pursuant to paragraphs 259 and 260 of Criminal Code. ${ }^{11}$

The crime of fraud is committed by someone who, at the expense of someone else's property, enriches themselves or someone else by misleading someone or takes advantage of someone else's mistake and thus causes a minor damage on someone else's property. Within the qualified merits by this crime it is possible to commit this crime and cause serious damage, commit crime by more serious kind of acts, from a specific motive, or against a protected person. Even more serious can be committing a crime and thus causing damage of significant scope, committing a crime as a member of a dangerous group or within a crisis situation.

The object of the crime of fraud is the right of ownership or possession. The subject can be any criminally liable person, i.e. there are required no specific attributes related to the subject. The subjective nature of the merits of the crime requires deliberate action.

For instance, inserting incorrect data by registration of the end user of benefits in the Register of Public Sector Partners can meet the merits of a crime.

The crime of subsidy fraud is perpetrated by someone who lures out of others a donation, subsidy, grant or other fulfilling of state budget, from budget of a public institution, state fund budget, higher territorial unit budget or municipal budget which provision or usage is, pursuant to generally binding regulation, bound to conditions which are not met by misleading in the matter of meeting these conditions. ${ }^{12}$ Furthermore, a subsidy fraud is perpetrated by someone who the obtained donation, subsidy, grant or other fulfilling of state budget, from budget of a public institution, state fund, higher territorial unit budget or municipal budget uses for other than the intended purpose, or by someone who as an employee, member, representative or another person authorized to act on behalf of someone who provides a donation, subsidy, grant or other fulfilling of state budget, from budge of a public institution, state fund budget, higher territorial unit budget or municipal budget allows someone to obtain others a donation, subsidy, grant or other fulfilling of state budget, from budget of a public institution, state fund budget, higher territorial unit budget or municipal budget while they know that the recipient does not meet the conditions for obtaining it. ${ }^{13}$

A subsidy fraud is a deliberate crime which aims on property rights and deliberate usage of received funds, subsidies or other contributions from public resources. This crime can be committed by the public sector partner as well as the authorized entity, particularly in one of the types of accounting. We can speak of a subsidy fraud, for instance, when the violation of obligation to register in the Register of Public Sector Partners has also led to obtaining finances from public funds.

The crime of misrepresentation of economic and commercial records is perpetrated by someone who lists incorrect or significantly misrepresenting data or withholds mandatory data on critical information in a statement, report, introductory data inserted in a computer or in other documents used for statistical examination in order to ensure for themselves or someone else illegitimate advan-

11 Explanatory Report to draft Register of Public Sector Partners Act.

12 https://www.slov-lex.sk/pravne-predpisy/SK/ZZ/2005/300/

13 https://www.slov-lex.sk/pravne-predpisy/SK/ZZ/2005/300/ 
tages, employee evidence in order to ensure for themselves or someone else illegitimate advantages, accounting control, control over usage of donations, subsidies or other fulfilling from state budget, from budget of a public institution, from state budget, from higher territorial unit budget or from municipal budget, definition of property price, or exchange rate of security by its transfer or change to another currency, bankruptcy, settlement, restructuring or debt relief, or registration in Commercial Code or Land Register, Motor Vehicle Register, or any other register pursuant to a specific regulation. Equally, this crime is perpetrated by someone who, with the intention to provide incorrect or significantly misrepresenting data on critical information, interferes with technical or program capacities of a computer or destroys or damages the listed documents or otherwise depreciates them. ${ }^{14}$

This crime can be committed by a deliberate act, but also by negligence, though by negligence the meeting of the merits of the crime of misrepresentation of economic and commercial records is condition for causing damage of a large scope only in the defined part of the act.

This crime can be, for instance, perpetrated in the sector of Register of Public Sector Partners in relation to verification documentation.

From the nature of the topic follows that the probably most often committed crime is the crime of fraud under which we can find a great amount of violations of obligation by registration of the public sector partners. In addition to the above mentioned crimes to which points the Explanatory Statement to the draft Register of Public Sector Partners Act, we can also consider possible meeting of the merits of the crime pursuant to provision paragraph 261 of Criminal Code, i.e. damaging the financial interests of the European Union, crime of abuse of authority of a public official pursuant to provision of paragraph 326 of Criminal Code, some of the crimes of corruption, eventually the crime of legalisation of income from criminal activities pursuant to paragraph 233 of Criminal Code.

In case of misconduct or a violation of obligation, this needs to have a certain degree of social relevance for criminal liability to occur, the so called material corrective.

\section{CONTRACT WITHDRAWAL AND CONTRACTUAL CONSEQUENCES}

A violation of obligations following from the above mentioned legal provisions cause the incurrence of the above mentioned administrative and criminal liability in the sector of public law. Considering that meeting of obligations related to the Register of Public Sector Partners also has an impact on private law, it is necessary to deal with consequences within the incurred contractual relationship. It is necessary it divide these into two areas, i.e. the incurrence of the contract withdrawal right (directly defined by private law regulations) and the area of contractual obligations agreed upon for the case of a violation of obligation directly by the contract itself.

\subsection{Contract Withdrawal on the Basis of Register of Public Sector Partners Act and on the basis of Public Procurement Act}

The impact of the Register of Public Sector Partners on private law relations can be observed especially by private law consequences of a violation of selected obligations regulated by Register of Public Sector Partners Act.

14 https://www.slov-lex.sk/pravne-predpisy/SK/ZZ/2005/300/ 
Specifically, it is the option to withdraw from a contract for the public sector in case the public sector partner has been imposed a fine for a violation of obligation to amend in data about the end user of benefits in the defined time limit or if by the public sector partner has been found violating the ban preventing the authorized entity to perform its function if they are at the same time a public sector partner or end user of benefits of the public sector partner for whom they should function as the authorized entity, the end user of benefits of the public sector partner and the authorized entity are the same natural person or if they have any relationship with the public sector partner or if they are a member their bodies which could call into question their impartiality, particularly if they are connected with the public sector partner on a personal or property level and the public sector partner has been erased from the Register.

Furthermore, the contract withdrawal right also arises to the public sector on the day of validity of the decision on erasure of the public sector partner from the Register of Public Sector Partners on the basis of the finding that the end user of benefits data in the Register of Public Sector Partners are not complete and correct.

The specific withdrawal right arises for an entity which provides finances, property, rights to property or other property rights. The contract withdrawal also arises for a contract participant if the public sector partner is delayed by more than 30 days to meet their obligation to select and register a new authorized entity in the Register of Public Sector Partners after the previous authorized entity had been erased.

The contract withdrawal right which arises as a consequence of a violation of obligation is also included in Public Procurement Act. The contracting authority and contracting entity can withdraw from a contract, framework agreement or a concession contract concluded with a candidate who, in the time of conclusion of contract, framework agreement or concession contract, has not registered the end users of benefits in the End Users of Benefits Register, or if it has been finally decided to erase this candidate from the End Users of Benefits Register.

This contract withdrawal right does not correspond with obligation for the contracting authority and contracting entity by conclusion of contract with the successful candidate as the obligation to register in the Register of Public Sector Partners is not only related to the candidate, but also to each one of their sub-contractors if they meet the conditions for mandatory registration in the Register of Public Sector Partners. Equally, the sanction for a violation of ban to conclude a contract, concession contracts or framework contracts with the entity which is not registered in the Register of Public Sector Partners is also imposed on the entity whose sub-contractors are not registered in the Register of Public Sector Partners. The authorization to withdraw from contract is only granted to the contracting authority or contracting entity only in the case of the contractor themselves and a violation of their obligation, not in the case of their sub-contractors. This is substantiated only in the private law nature of the contractual relationship, as well as the contractual relationship termination through the legal act of withdrawal. A violation of obligation of the third person cannot establish the right to carry out the private law act between other entities which have not directly violated this obligation. This can only be arranged within contractual freedom by conclusion of the contract itself.

In both cases of the contract withdrawal rights which are established by public regulation there is a question whether the public sector is obliged to use this right. As only the contract withdrawal right follows from Register of Public Sector Partners Act and from Public Procurement Act, the public sector is not forced to withdraw from the contract. On the other hand, there is the liability of the statutory representative of the public sector, as well as the assessment whether the 
not used contract withdrawal right and maintaining the contract concluded in a violation with regulations, resp. which has become a contract in a violation with regulations is not a violation of their obligation.

The provisions of Commercial Code which deal with the liabilities of the executive manager of a limited liability company impose the obligation to perform their actions with professional care and in accordance with interests of the company and all its partners. The executive managers are, in particular, obliged to gather and by decision-making consider all available information related to the subject of decision-making, keep confidential on sensitive information and facts which disclosure to third persons could damage the company or endanger its interests or the interests of its partners, and by carrying out their actions they must not prioritize their own interests, interests solely of a few partners or interests of third persons at the expense of the interests of the company. ${ }^{15}$ Equally, in case of joint stock companies Commercial Code in paragraph 194 imposes on the joint stock company members the obligation to carry out their actions with proper care which involves the obligation to carry it out with professional care and in accordance with the interests of the company and all its shareholders.

Contract withdrawal thus remains a right, however, the statutory body is obliged to deal with not using this right if it does not make the decision to withdraw from the contract. The statutory body thus needs to examine all required information and thoroughly analyse what is the best course of action to take for the company on which behalf it acts.

For completeness it is necessary to point to other provisions of Commercial Code, specifically paragraph 135 (a) (3) pursuant to which the executive manager is not liable for damage if it is demonstrated that they acted with professional care and in good faith that they acted for the interests of the company, as well as paragraph 194 (7) of Commercial Code which similarly deals with the possibility of clear the board of directors of guilt.

By assessment of advantage, resp. suitability of the contract withdrawal right usage it is necessary to consider the impact of the contract termination on the society and its functioning. For the executive manager or member of the board of directors it should be more important to protect the interests of the commercial company before the interests of the entire society to identify and publish the end users of benefits arising from making business with the state. It is necessary to consider whether the termination of a contract which is irreplaceably necessary for the society to function is not itself in contradiction with the interests of the society and whether it will not cause damage for which the statutory body will be held accountable.

\subsection{Contractual Fines by Violation of Obligations Following from Register of Public Sector Partners Act}

Taking into account the contract withdrawal right following from Public Procurement Act and Register of Public Sector Partners Act which, however, does not cover all the possible violations of obligations arising in the connection with the Register of Public Sector Partners. In the context of preservation of contractual freedom, it is therefore good to consider the control over meeting the listed obligations, sanctions for their violation, as well as the possibilities to terminate a contractual relationship.

15 https://www.slov-lex.sk/pravne-predpisy/SK/ZZ/1991/513/20160701?ucinnost=17. 11. 2019 
To evade the incurrence of liability for a violation of obligations related to the Register of Public Sector Partners it is optimal to demonstrate meeting them in relation to the other contracting party as well. This is practical and appropriate particularly by the control over obligation meeting on the part of individual sub-contractors over which the public sector does not exercise any direct influence and thus, in particular, by extensive contracts with a large group of sub-contractors represent a heavy burden on the public sector's administrative capacities. In this case it is appropriate to move the liability on the contractor themselves who as a contract party answers directly to the public sector. Considering that the majority of contracts shall be concluded pursuant to Commercial Code in order to ensure meeting the listed obligations, it is appropriate to use an ensuring institute.

In connection with this it seems appropriate that the public sector partner who, at the same time, is a contract party shall accept contractual obligation to meet obligations of their sub-contractors. In case of a violation of obligations of the public sector partner it is appropriate to agree upon a contractual ensuring institute like a contractual fine. At the same time, to ensure the settlement of the arranged contractual fine it is also appropriate to arrange the guarantee deposit and the subsequent possibility of offsetting the contractual fine.

In addition to this, it is also possible to agree to other reasons for contract withdrawal than those following from Register of Public Sector Partners Act or Public Procurement Act, as well as from Commercial Code. One of such reasons can also be a violation of obligation to register in the Register of Public Sector Partners.

\section{CONCLUSION}

The Register of Public Sector Partners is a unique concept to improve transparency for used public funds. Publicity of individual relationship is one of the best tools for public control over management of state property.

By the Register of Public Sector Partners, we can see the aim to provide a complex legal provision which should cover the widest area of social relations possible. From this complex legal provision follows a variety of bilateral liability relationships. At the same time, for different entities there is a variety of sanctions for a violation of individual liabilities.

In spite of the effort to provide complex legislation there are still some areas left uncovered. One of these can be, for example, withdrawal from contract, which is left at the level of possibility, whereas the termination of the contract directly by law would seem to be more effective. Of course, this would have immediate consequences on the public sector, however, it could ensure more consistent adhering to obligations of the Register of Public Sector Partners.

As another problematic area can be seen withdrawal from contract if obligations following from Register of Public Sector Partners Act are violated by a sub-contractor. If the option to withdraw from the contract is not agreed upon before the violation by the contractual partners in the contract, the public sector partner shall need to review whether this violation is a case of a significant violation pursuant to Commercial Code. With taking this into account, as well as to simplify the process on the part of the public sector it would be perhaps optimal to amend as a reason for withdrawal from contract the violation of liabilities following from Register of Public Sector Partners on the part of the sub-contractor as well. 
In conclusion, it needs to be said that individual responsible bodies should consistently impose sanctions as the legislation in cases of a violation of obligations entitles them to.

\section{Bibliography:}

Explanatory Report to draft Register of Public Sector Partners Act

GRIGA, M., TKÁČ, J. Public Procurement Act. Commentary. Bratislava : Wolters Kluver, s. r. o. 2016. 630 pages. ISBN 978-80-8168-454-8

MACHAJOVÁ, J. General Administrative Law. 7. Updated edition. Žilina : EUROKÓDEX. 2014. 708 pages. ISBN 97880-8155-044-7

ŠEVČÍK, M. Administrative Procedural Law. Updated edition. Žilina : EUROKÓDEX, spol. s r. o. 2007. 177 pages. ISBN 978-80-88984-93-1

https://www.slov-lex.sk/pravne-predpisy/SK/ZZ/2008/297/\#

https://www.justice.gov.sk/Stranky/Registre/Dalsie-uzitocne-zoznamy-a-registre/RPVS/FAQ.aspx

https://www.slov-lex.sk/pravne-predpisy/SK/ZZ/2015/343/20160418.html

https://www.slov-lex.sk/pravne-predpisy/SK/ZZ/1990/372/

https://www.slov-lex.sk/pravne-predpisy/SK/ZZ/2005/300/

https://www.slov-lex.sk/pravne-predpisy/SK/ZZ/1991/513/20160701?ucinnost=17. 11. 2019

\section{Contact information:}

Mgr. Zuzana Kršjaková

zuzana.krsjak@gmail.com

Office for Public Procurement

Director of Legal Division

Ružová dolina 10

82109 Bratislava

Bratislava

Slovak republic 